\title{
TURN TO POSTMODERNISM \\ IN JOSE ORTEGA Y GASSET'S WORKS AND THE PRESENCE OF POSTMODERNITY FEATURES IN MODERNITY
}

\section{Olha Smolina}

\section{INTRODUCTION}

The concepts of "modernism" and "postmodernism" (or "modern" and "postmodern" in usage on post-soviet scientific space and "modernity" and "postmodernity" in English-language literature) $)^{1}$ today are widely used in a scientific context. At the same time, the scatter of their meanings, understandings, and definitions is very large. There is no consensus among scientists on the chronological framework of periods indicated by these concepts. This fact actualizes the continuation of research to identify the specifics of the concepts of modernity and postmodernity, as well as the phenomena that they designate.

In the context of this problem, the judgments and conclusions of the Spanish philosopher José Ortega y Gasset are interesting. The study of his work is relevant due to the unresolved circle of cultural and philosophical problems and questions that he posed at the beginning of the twentieth century for the world culture (and above all - European culture) of our time.

The work of Jose Ortega y Gasset as a whole is characterized by trends inherent in the culture of the first half of the twentieth century, which are usually collectively defined as the period of modern, modernism, and avantgarde. At the same time, in a significant part of Ortega's work, we can notice the trends of the next period, which became significant in the second half of the twentieth - the beginning of the twenty-first century, the tendencies of postmodernity and postmodernism. What is the reason for this phenomenon? Is this the result of creative insights of a gifted person or the implicit presence of postmodernity features in modernity, or maybe this is a consequence of the blurriness and uncertainty of the distinguished stages boundaries in worldview and culture, which are conventionally defined as "modernity" and "postmodernity"? Naturally, it is hardly possible to unambiguously and fully study the problem and answer these questions in the framework of one article.

Therefore, the purpose of this article is to expand the understanding of Jose Ortega y Gasset's cultural studies, to identify the features of

\footnotetext{
${ }^{1}$ In this work, the concepts of "modernism" and "modern" are used as synonyms. The same applies to the concepts of "postmodern" and "postmodernism".
} 
postmodernity thinking and reality that are not directly mentioned, but actually were seen by him in the phenomena and processes of culture of the first half of the twentieth century. Then the consideration of the data in a wider context - in the aspect of the problem of insufficient certainty of the essence and chronological framework of modernity and postmodernity as stages of development of European culture.

The material used for analysis was some Jose Ortega y Gasset's works such as "Reflections on Don Quixote", "Dehumanization of Art", "Poverty and Shine of Translation", "Reflections on the Novel", "Summer Sonata", "Adam in Paradise", works a number of Ukrainian and foreign researchers, as well as publications by Spanish scientists, including modern ones, in translations of this article author.

\section{Jose Ortega y Gasset and postmodernity}

Jose Ortega y Gasset (1883-1955) - the world-famous Spanish philosopher, publicist, essayist, writer. Because a significant part of his work is devoted to the analysis of contemporary trends in culture and art, he has recently been also considered as a culturologist. The most famous of his concepts remain the philosophical idea of ratiovitalism, the culturological ideas of art dehumanizing, the massization of man, art and society. Ortega's works are a synthesis of philosophy, aesthetics, thoughts about various aspects of culture, about art and literature. Jose Martin Francisco, however, notes that Ortega felt the calling of a writer and publicist before the calling of a philosopher ${ }^{2}$.

A study of Jose Ortega y Gasset's works represents a significant body of publications and has a long tradition (in Spain, it begins immediately after Ortega's death) $)^{3}$. A number of Spanish researchers have already paid attention to the presence in the work of the ideas and statements that are more consistent with postmodern thinking than with the ideas of the first half of the twentieth century. Overall, these facts have not been adequately studied either in cultural studies as well as in other areas of humanitarian knowledge.

So, one of the modern Spanish researchers, Jacinto Sánchez Miñambres, in the context of analyzing Ortega's work "The theme of our time" draws attention to the question of his possible connections with the modern direction, which is called "postmodernism". He suggests considering this short essay as one of the reference texts of the early postmodernism. As evidence of such a judgment Jacinto Sánchez Miñambres proposes a quote from Ortega's cited work "everyone starts with more or less embarrassment,

\footnotetext{
${ }^{2}$ Martín Francisco J. (2006) La teoría de la traducción en Ortega. Centro Virtual Cervantes. pp. 1-10. Retrieved from: https://cvc.cervantes.es/literatura/aispi/pdf/06/06_245.pdf (in Spanish).

${ }^{3}$ It is noteworthy that for Ukrainian or Russian researches Ortega is more considered as a philosopher, but for Spaniards he is a writer, publicist, and essayist.
} 
to want something unconditionally, and then looks for evidence to show that

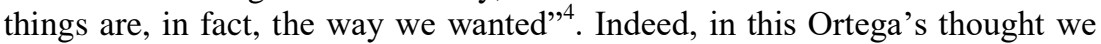
can see a rejection of the dominant role of reason, subjectivity, arbitrariness of will in relation to consciousness.

Another Spanish researcher, Jose Luís Abellán García, writes that in the literary association "Generation 14", to which Ortega y Gasset belonged (and actually he headed it), the features of postmodernism are clearly visible: the rejection of not only philosophical positivism and the legacy of the $19^{\text {th }}$ century, but denial of modernist tendencies. This was manifested in Ortega's works in the most radical form ${ }^{5}$,

Analyzing reflection on the translation of Ortega y Gasset, Pilar Ordóñez López notes that the work of the thinker "Poverty and Shine of Translation" can be understood only within the limits of intertextuality applicable to the whole work of Ortega. The concept of intertextuality, as it is known, also belongs to the postmodern views.

The Portuguese researcher C. Gomes, in his eloquent title "Ortega y Gasset: on the way to hypermodernism", identifies several topics in the work of the Spanish writer, which are at the same time precursors of postmodernity trends, namely:

1) alignment, destruction of the value hierarchy of times and societies;

2) banalization and populism of aesthetic tastes and trends;

3) the emergence of individualism / narcissism and its dissatisfaction with society;

4) substantiation of the "I" and his dissatisfaction with the political and ideological aspects;

5) the growing influence of the media and monopolies, which provoke increase consumer demands of population ${ }^{6}$.

Fernando Candón Ríos draws our attention to the fact that in 1951, Ortega had announced the death of modernity in connection with the end of the concept of methanarratives ${ }^{7}$.

${ }^{4}$ Sánchez Miñambres J. (1996) Ortega y el nacimiento de la posmodernidad. El Basilisco (Oviedo). no. 21, pp. 62-63. (in Spanish).

5 Abellán García J. L. (2005) Ortega y Gasset, adelantado de la postmodernidad. Meditaciones sobre Ortega y Gasset. Madrid, p. 597. (in Spanish).

${ }^{6}$ Gomes C. (2018) Ortega y Gasset: no caminho da hipermodernidade. Uma visão projetiva da Contemporaneidade. Ideas y Valores, vol. 67.168, pp. 43-57. (in Spanish).

${ }^{7}$ Candón Ríos F. La literatura posmoderna española: entre el fin de la dictadura y el auge de los mass media. Verba hispanica XXIII, p. 187. (in Spanish).

The author writes: "Curiosamente, aproximadamente veinte años después en clara sintonía con este pensamiento, Umberto Eco y John Barth teorizarían sobre la posmodernidad utilizando estos términos. Fuentes continúa su artículo haciendo alusión a un hito que resultó ser un punto de inflexión en lo que se refiere al reconocimiento del nuevo paradigma posmodernista: En 1951, 
Anastasio Ovejero Bernal considers a recognition of the crisis of positivist science (social science and natural sciences) and traditional positivistic psychology as one of the main contributions of Ortega to the development of Spanish humanities. Recognizing that Nietzsche, Husserl and Heidegger had a great influence on Ortega's worldview, Anastasio Ovejero Bernal believes that it would be an exaggeration to consider Ortega as a philosopher of postmodernism, but "I have no doubt that he can be called a philosopher of pre-postmodernism" 8 . In addition, the researcher writes: "When in December 1992 I presented a report on the "perspectivizm" of Ortega in Lisbon, insisting on the existence of some similarities with postmodernity thinking, Professor F. Jimenez Burillo answered me energetically, emphasizing the impossibility of calling the a person a philosopher of postmodernity who, like Ortega, was a metaphysician whose main longing was the search for truth. <...> But Ortega, in his search for truth, was influenced first by Nietzsche and Heidegger, followed the path that I dare to name in quotation marks "postmodern"?

Among domestic researchers, one can also see certain remarks of Jose Ortega y Gasset observations and intentions about the postmodernity. In particular, Alexander Pronkevich notes that in his work "Reflections on Quixote" Ortega denies the model of "romantic Don Quixote", which was dominant throughout the 19th century, and replaces it with a "perspective" approach, which serves as the basis for a postmodern interpretation an immortal novel ${ }^{10}$. Also Mariya Moklitsa concludes that Ortega y Gasset considers a real vision only a vision of the world through the prism of the concept ${ }^{11}$. Tatiana Lisokolenko focuses on the concept of "game" as important for Ortega's work ${ }^{12}$.

cuando se empieza a reconocer al nuevo movimiento, Ortega y Gasset, uno de los precursores españoles, anuncia en su célebre coloquio de Darmstadt "la muerte de la modernidad " debido al fin de la idea de los metarrelatos".

${ }^{8}$ Ovejero Bernal A. (2000) Ortega y Gasset un pensador pre-postmoderno altamente fertil para la psicologia postpositivista del siglo XXI. Revista de historia de psicilogia. vol. 21, no 2-3, p. 43. (in Spanish).

${ }^{9}$ Ibid.

${ }^{10}$ Pronkevych O. V. (2006) "Rozdumy nad Kikhotom" Kh. Ortehy-i-Hasseta: ispanska natsionalna identychnist yak kontaktna zona. ["Reflections on Quixote" by J. Ortega y Gasset: Spanish National Identity as a Contact Zone] Naukovi pratsi MDHU im. Petra Mohyly, vol. 59, no. 46, pp. 42-47. (in Ukrainian).

${ }_{11}$ Moklytsia M. (2016) Poniattia "zhanr" i "styl" yak fenomen humanitarnykh nauk ("Rozdumy pro Dona Kikhota" Kh. Ortegy-i-Hasseta) [The notion of "genre" and "style" as a phenomenon of the humanities ("Reflections on Don Quixote" by J. Ortega y Gasset)] Literaturnyi protses: metodolohiia, imena, tendentsii. Filolohichni nauky. no. 8, p. 21. (in Ukrainian).

${ }^{12}$ Lisokolenko T.V. (2015) Igra kak fenomen kul'tury v opisaniyakh Y. Kheyzingi i Kh. Ortegi-i-Gasseta [The game as a cultural phenomenon in the descriptions of J. Hazinga and J. Ortega y Gasset] Aktualni problemy filosofii ta sotsiolohii. pp. 88-90. (in Russian). 
Russian researcher Lyudmila Gorbunova calls Ortega "one of the most perspicacious thinkers of the twentieth century", a number of whose ideas have remained underestimated in life and are now gaining relevance. Referring to a number of his works, Lyudmila Gorbunova highlights the following features of postmodernity thinking: a sense of the superiority of our time over any other eras, a lack of faith in patterns and ideals, an increase in life's demands, unbridled expansion outside of one's own nature, and innate ingratitude ${ }^{13}$.

Familiarity with the work of Jose Ortega y Gasset allows as complementing the above series of signs and characteristics that he identified in his contemporary culture, but which do not quite fit into the traditions of the first half of the twentieth century.

So, in the work "Reflections on Don Quixote", Ortega writes: "It is easy to make sure that what is really real for us is not what is actually happening, but some kind of routine of events that is familiar to us. In this foggy sense, it's real not so much what is seen as what is foreseen, not so much what we see, but what we know." 14 Here the thinker talks about subjectivity in the perception of reality.

The widely known Ortega's work "The Dehumanization of Art," has a particular interest from the perspective of this study subject. That work is dedicated not only to the visual arts, but also to literary creation. According to the thinker, the new style of art seeks to: de-humanize art (it is known that the concept of dehumanization, by the definition of Ortega, means deprivation of the art of human presence - sensual, figurative, emotional, intellectual components). To consider art only as a game and nothing more, to be deeply ironic, to perceive art as something frivolous, not affecting human being. The features noticed by Ortega are common with the postmodern thesis of "the death of the author" and the following "death of a person".

An analysis of contemporary art provides Ortega with the opportunity to identify means of dehumanization, among which he names the following:

- metaphor (constitutes a radical way of dehumanizing);

- a change in ordinary perspective;

- infrarealism (violation of the existing hierarchy of values);

- dives below the level indicated by a natural perspective.

In his work "Poverty and Shine of Translation" Ortega, tells, on the one hand, the barriers for the most adequate translation of the original text essence

13 Gorbunova L.I. (2011) Postmodern kak tendentsiya razvitiya kul'tury XX veka [Postmodernism as a trend in the development of culture of the twentieth century.] Vestnik $M G T U$, vol. 14, no. 2, pp. 265-271. (in Russian).

${ }^{14}$ Ortega-i-Hasset Kh. (2012) Rozdumy pro Dona Kikhota [Reflections on Don Quixote] / per. $z$ isp. H. Verby. Kyiv: Dukh i Litera, p. 127. (in Ukrainian). 
into the target language. On the other hand, he empathizes on the possibilities and advantages of the translation as such for literary and public life and the formation of a worldview. Ortega notes: "So, I see a form of translation that would be ugly, science is always ugly, would not pretend to literary excellence, which would not be easy to read, but that would be extremely clear, even if that I clearness took many notes at the bottom of the page" ${ }^{\text {. }}$. In the above discussion, the image of translation as a hypertext clearly arises, each incomprehensible place, original construction, neologism or reality of which entails a transition to other places in the text or to other texts associated with the previous one.

Another interesting observation concerns the author's position of Ortega in the essay "Reflections on the novel". The author, writes Ortega, referring to the example of impressionist artists, should leave on the canvas only the most necessary for the reader to independently finalize the material. "We are as if observing things in their eternal status nascens (that is, at the time of birth O.S.)" ${ }^{\text {"16 }}$. In this case, we can see the unity of the principle that Ortega proclaims, with a postmodern perception of the world and things in it, which was called "from being to becoming".

For Ortega, science is identical to the language: "For science, things are not significant, but a sign system that can replace them" $" 17$. Here, the author envisages the principle of post-non-classical science, which has no longer characteristics (in contrast to its classical stage) such as: naive realism with respect to cognition of the world in its absolute reality and knowledge the truth through contemplation and sensory organs.

Ortega contrasts art (and also literature) with science:

- science goes from things to a sign system, which operates instead of things;

- art goes from the familiar sign to the thing itself.

The art of "good drawing" allows as to see what is elusive for everyday contemplation, as well as rational scientific knowledge. Here Ortega is also ahead of time, revealing the need for mutual complementarity of humanitarian and natural science knowledge.

In addition, in the same work, turning the reader's attention to various aspects of his contemporary novel - to worldview, consciousness, social life

15 Orteha-i-Hasset Kh. (2009) Ubohist i blysk perekladu. [Poverty and brilliance of translation] Vsesvit. no. 11-12. Retrieved from: http://www.vsesvit-journal.com/old/content/ view/659/41/ (in Ukrainian).

${ }^{16}$ Orteha-i-Haset Kh. (1994) Dumky pro roman [Thoughts on a Novel] / per. V. Sakhna. Vybrani tvory [Selected Works.] Kyiv: Osnovy, pp. 273-305. Retrieved from: https://www.ukrlib.com.ua/world/printit.php?tid=3815. (in Ukrainian).

${ }^{17}$ Ibid. 
and culture as a whole, Ortega changes not only the perspective of the problem, but he himself appears, so to speak, in different guises. As an author (writer, novelist), he discusses the upcoming topics of the novel and its impact on readers. As a critic (objective observer), he gives advice to the author, substantiates the features of the genre and "polishes" it. Finally, as a reader, he writes about the feelings that the reader experiences when immersed in the world of the novel, about their, readers, preferences and wishes. It can be noted that such a kaleidoscopic position of the artistic work author is inherent to a greater extent in postmodern literature.

In "Summer Sonata" Ortega describes fake as a line of decadence ${ }^{18}$, but the same characteristic can be attributed to the art of postmodernism. He also points to the recombination of the old as a way of creating the new (which is also inherent in the culture of the late twentieth century): "this joy is to give words a new sound, combining them in a new way"19. According to Ortega, this joy and a kind of combination art are provided not only by rich life experience, but also by the property of "not being very attached to the homeland" $"$. This property noted by Ortega can be called cosmopolitanism or postmodernity (somewhat paraphrasing J. Derrida) "anti-topo-ethno-phono-centrism".

Ortega's small work "Adam in Paradise" provides enough evidence to attribute its author to the predecessors of postmodernity. For example, Ortega expresses distrust of reason and speaks about impossibility of objective judgment: "No opinion is possible without bias" ${ }^{21}$. He characterizes culture as an accumulation of prejudices: "Logic, ethics and aesthetics are three such prejudices, thanks to which a person rises above the natural world and, relying on them like piles, intelligently and freely erects a cultural building <...> without this traditional accumulation of prejudice, there is no culture" $22 . \mathrm{He}$ speaks of pluralism of points of view on reality and, accordingly, the absence of reality as such: "There is no single and unchanging reality by which works of art can be verified; there are as many realities as points of view" ${ }^{23}$. Ortega characterizes the causal relationship of the phenomena in controverse way to the classical understanding: "vision appeared for the first time not thanks to the optic nerves and retinal rods; on the contrary, the need for vision, the very act of vision, created an instrument for itself ${ }^{, 24}$. In addition, the author

${ }^{18}$ Ortega-i-Gaccet Kh. (1991) Estetika. Filosofiya kul'tury. [Aesthetics. Philosophy of Culture] Moscow: Iskusstvo, p. 52. (in Russian).

${ }^{19}$ Ibid.

${ }^{20}$ Ibid, p. 57.

${ }^{21}$ Ibid, p. 60.

${ }^{22}$ Ibid.

${ }^{23}$ Ibid, p. 62

${ }^{24}$ Ibid, p. 66. 
actively uses the concepts of trick, virtuality, imaginary: "art is essentially a trick; it must create a certain virtual world. The infinity of relationships is unattainable; art seeks and creates a kind of imaginary aggregate - like infinity" ${ }^{25}$.

After analyzing the above opinions of foreign and Ukrainian scientists, we can state the following:

1) a significant group of researchers of Jose Ortega y Gasset's work see enough reason to attribute it, if not to philosophers of postmodernity, then to the predecessors of this trend, the so-called "pre-postmodernism";

2) the mentioned above foreign and Ukrainian researchers see in Jose Ortega y Gasset's works a rather wide range of features inherent in postmodern thinking, namely: rejection of the dominant role of reason, subjectivity, arbitrariness of will in relation to consciousness; intertextuality; the destruction of the value hierarchy, the populism of aesthetic tastes, narcissism, the increasing influence of the media and their modeling of consumer demands of the population; the proclamation of the end of the era of metanarratives, unbridled expansion outside the personal nature of man-mass.

3) this list of postmodern features in Jose Ortega y Gasset's works can be supplemented by a number of characteristics identified by the author of this article, namely:

- dehumanization as "the death of the author" leading to the "death of a person";

- hypertectuality, perception of reality as an eternal process of formation, and not of being itself;

- kaleidoscopic position of the author of an artistic work;

- pluralism of realities and the absence of reality as such (in fact, understanding reality as a simulacrum);

- tricks, virtuality, imaginary in culture and art;

- "anti-topo-ethno-phono-centrism".

\section{Modernity and postmodernity, modernism and postmodernism:} approaches to the definition of essence, chronology, correlation

Speaking about the belonging of Jose Ortega y Gasset's work to modernity and its prediction of postmodernity, it is necessary, as far as possible, to clarify the meaning that is embedded in these designations of cultural periods. There is no unity among scientists on this issue. Most of the available points of view can be grouped into the following main positions:

1. "Modern" and "postmodern" are scientific and philosophical directions, and modernism and postmodernism are directions of culture and

\footnotetext{
${ }^{25}$ Ibid, p. 72.
} 
art. So, A. Ya. Flier writes: "Postmodern, as a scientific and philosophical direction, should not be confused with postmodernism, as a direction of literature and art, using some ideas of scientific postmodern and ironically rethinking the classics (novels by U. Eko, M. Pavich, V. Pelevin, music by J. Cage, films of P. Greenaway)" ${ }^{\text {"26 }}$. This point of view is close to that established in English-language literature, where "modernism" and "postmodernism" are the designations of directions in literature and art, and the concepts of "modernity" and "postmodernity" are used to highlight periods in the culture of the twentieth century.

2. Modern and postmodern are stylistic directions in art, and modernism and postmodernism are forms of worldview that oppose themselves to the traditional worldview ${ }^{27}$.

3. Modern and postmodern are the names of cultural eras. But modernism and postmodernism, respectively, are "advanced units" or the dominant directions of development in these eras ${ }^{28}$.

4. The pairs "modern" and "modernism" and, accordingly, "postmodernism" and "postmodernism" are interchangeable, synonymous concepts ${ }^{29}$.

\footnotetext{
${ }^{26}$ Flier A.Ya. (2000). Kul'turologiya dlya kul'turologov. [Cultural Studies for Culturologists] Moscow: Akademicheskiy Proekt. P. 170. (in Russian).

${ }^{27}$ In the work of A. Panishchev we read: "Modern is a style direction in art, which originated in the search for new forms and eclecticism. This trend is characterized by symbolism, the desire to combine several artistic styles in one form; the rejection of the former laws of academism and the search for new patterns in art; the desire to express, find other forms of art that most vividly express individuality; as well as using new technologies. Of course, modern (Art Nouveau - O.S.) was not the only leading direction in the art of the twentieth century, but still it played a significant role in the development of a number of arts. Modern (Art Nouveau - O.S.) was especially pronounced in architecture, graphics, decor, poetry and music.

Modernism is a form of worldview that contrasts itself with a traditional worldview. Within the framework of modernism, a number of directions in art have developed: avant-garde, Fauvism, Suprematism, constructivism, primitivism, cubism, futurism, abstractionism, surrealism, dadism, neoplasticism. These trends in art took shape under the significant influence of the recently developed psychology of the Freudian idea of the unconscious". Panishchev A.L. (2009) Kul'turologiya [Cultural studies]. Moscow: Soyuz, p. 315-316. (in Russian).

${ }^{28}$ V.A. Kutyrev writes: "Terminologically, the difference between the actually existing content of social life and the direction of change is fixed by the so-called "ism". We distinguish the society and era of modernity and - modern-ism. Society and era of postmodern and postmodern-ism. <...> Modernism is an advanced detachment of the modern era. Postmodern is an era, a society as a whole with everything that exists in it. Postmodernism is the dominant direction of development in the postmodern era". Kutyrev V.A. (2006) Filosofiya postmodernizma [The philosophy of postmodernism], Nizhniy Novgorod: Volgo-Vyatskoy akademii gosudarstvennoy sluzhby, 95 p. (in Russian).

${ }^{29}$ I.P. Ilyin uses the concepts of "postmodern" and "postmodernism" as interchangeable: "The inconsistency of modern life is such that it does not fit into any intelligible framework and inevitably gives rise to explanations that are no less phantasmagoric than she herself, concept. Perhaps the most influential of these chimera concepts is postmodernism. Have born at first as a
} 
The question of the chronological framework of modernism and postmodernism? Modernity and postmodernity also does not have an unambiguous solution today.

According to Jürgen Habermas, the word "modern" was used at the end of the 5th century to distinguish between the Christian present and the pagan Roman past. In the perception of historical time as "new" for a long time, the decisive factor was the distance in relation to not the Middle Ages, but to antiquity. The concept of "modernity" or "belonging to the present" expressed only the consciousness of an era that correlates with antiquity. And only with the emergence of the enlightenment idea of endless progress, does the idea of "modernity" break with antiquity and only the opposition of tradition remains ${ }^{30}$. Therefore, Yu. Habermas actually claims that Art Nouveau is periodically inherent in any historical time and stage of development of culture.

The scatter of opinions of modernism and modernity emergence suggests the mobility of the chronological framework of the period.

Modernism at the turn of the nineteenth and twentieth centuries is so profoundly different from the modernism of the seventeenth and eighteenth centuries, which, of course, implies the existence of any reason for the usage of one name for such different phenomena. However, if we understand modernism as a worldview focused on the denial of traditional foundations, then its chronological framework will not be of fundamental importance. To solve this problem Beardsley proposes to consider the concept of "modernism" in two senses: in the broad sense, this is the modern age, including the time of Galileo, Descartes, Newton, as well as rationalism and scientism. In a narrow sense, modernism is a period of artistic and cultural activity at the beginning of the twentieth century ${ }^{31}$.

In accordance with one of the modern points of view (Nikolay Khrenov), "modernism" or "modern design" means the period from the Renaissance to the second half of the twentieth century, characterized by increasing influence and dominance of Western European man's worldview, his "Faustian" type,

phenomenon of art and realizing itself at first as a literary movement, postmodernism was then identified with one of the stylistic trends in architecture of the second half of the century, and already at the turn of the 70s and 80s it was perceived as the most appropriate expression of the intellectual and emotional perceptions of the era." Il'in I.P. (1998) Postmodernizm ot istokov do kontsa stoletiya: evolyutsiya nauchnogo mifa. [Postmodernism from its beginnings to the end of the century: the evolution of scientific myth]. Moscow: Intrada. 250 p. Retrieved from: http://www.gumer.info/bogoslov_Buks/Philos/Ilin_Mod/index.php (in Russian).

${ }^{30}$ Khabermas Yu. (2003) Filosofskiy diskurs o moderne. [Philosophical Discourse on Art Nouveau] Per. s nem. Moscow: Ves' Mir, 416 p. (in Russian).

${ }^{31}$ Beardslee W.A. (1989) Christ in the Post modern Age: Reflections Inspired by Jean Francois Lyotard. Varieties of Postmodern theology. Albany. p. 63-64. 
such as Protestant, entrepreneurial. In addition, the emergence of postmodernism, respectively, is associated with fatigue from the dominance of this type, which begins to manifest itself in the romanticism of the nineteenth century $^{32}$. Therefore, according to Nikolay Khrenov, postmodernity already had begun in the second half of the nineteenth century.

As for the artistic style itself, which is commonly called "modern", it is believed that it was established in the 80-90s. of the nineteenth century (Dmitry Sarabyanov). A similar understanding of "modern" is given to us by art history, however, for a philosophical analysis of modernism as an intellectual trend, it cannot be considered the main one, since the specifics of the worldview of modernism cannot be revealed within the framework of art history alone.

Most scholars believe that the transition from modernity to postmodernity occurred precisely in the mid-50s.

However, Natalia Avtonomova, considering the mechanism of changing artistic styles, comes to the conclusion that postmodernism is not a chronologically designated stage or trend in the culture of the second half of the twentieth century, but a peculiar reaction to certain principles of artistic trends or styles. That is, each cultural-historical era has its own post-modern reaction. The philosopher sees the positive significance of postmodernism in "restraining hasty, illusory synthesis", in "honing sensitivity to life and cultural diversity", in "developing the possibility of existence in oneself without any predefined guarantees"33. That is, the position of Natalia Avtonomova on the chronology of postmodernity is generally similar to the above position of Jürgen Habermas regarding the time of the beginning of the modern era.

Valentin Ratnikov's point of view is characterized by clarity in the question of the difference between modernity and postmodernity as the worldview positions. In his opinion the following features are inherent to modernity: faith in the power of the human mind, the development of objective science and objective knowledge, an attempt to free philosophy, science and culture from irrationality, adopting of the idea of progress to the various fields of public life, the desire to develop universal norms of morality and law, and also the general criteria of aesthetic, etc. However, postmodernism is a direction that criticized these representations, and the author relates its beginning to the second half of the nineteenth century ${ }^{34}$.

${ }^{32}$ Khrenov N.A. (2006). Volya k sakral'nomu [The will to the sacred]. St. Petersburg, Aleteyya. 571 p. (in Russian).

${ }_{33}$ Avtonomova N.S. (1993) Vozvrashchayas' k azam: Postmodernizm i kul'tura [Returning to the basics: Postmodernism and culture]. Voprosy filosofii, no 3, pp. 17-22. (in Russian).

${ }^{34}$ Ratnikov V.P. (2002). Postmodernizm: istoki, stanovlenie. [Postmodernism: Origins, Formation] Filosofiya i obshchestvo. no. 4, pp. 120-121. (in Russian). 
We can see that the above opinions have common ground in the following aspects:

- "modern" and "postmodern" as a negation of their previous types of culture and they probably do not localized in the framework of the twentieth century, but had taken place earlier and, in general, can be periodically repeated in the history of human culture development;

- modernity (if we consider that period of history of European culture from the Renaissance to the middle of the twentieth century) is heterogeneous in its characteristics.

In addition, the question arises of relating the phenomenon of avant-garde of the early twentieth century with the cultural periods under consideration. Traditionally, avant-garde is considered to belong to the "modernity". Nevertheless, there are series of discrepancies between the worldview of the era and the ideology of most representative artistic trends of avant-garde:

- modernity insisted on the existence of the universe objective laws and the need for their knowledge, but the expressionism told about the subjectivism in perceiving the world as suffering and writhing in convulsions;

- modernity seek to expel all irrationality, but abstractionism and surrealism appealed to it;

- naive realism in perception of reality was inherent in modernity, but cubism insisted on the discrepancy between the visible and the essential;

- modernity proclaimed the cult of reason, but surrealism appealed to the unconscious, etc.

Consequently, avant-garde chronologically attributed to the modern era, contains features inherent in postmodernism. Here again, as in the case of the work of José Ortega y Gasset, we encounter the presence of postmodernity in modernity. Given this, we should recognize that the period in the development of European culture, starting from the last third of the 19th century, is no longer modernity as such, but a transitional stage on the path to postmodernity.

In a certain sense, any period of culture development, located between two other periods, can be considered as transitional in relation to them. However, we cannot say that Antiquity was a transitional stage from the era of ancient civilizations to the Middle Ages. Similarly, the Middle Ages, possessing an independent status on the scale of cultural European time and unique characteristics, cannot be considered as a transitional era from Antiquity to Renaissance. The Renaissance, however, has already been accepted (in accordance with one of the approaches) as a transition from the Middle Ages (premodern, traditional society) to the New Time (modern, industrial society). The basis for giving the Renaissance the status of a transitional era is the emergence and gradual development of all those features that are fully manifested in the New Time. 
Maybe the modern era should be considered as a transitional period with respect to Postmodern (on the same grounds and given a number of facts revealed)? Arguments in favor of such a point of view besides the ones mentioned above can be, for example, the works of Nietzsche, Heidegger, Freud, who are usually considered as representatives of modernity and precursors of postmodernity at the same time. The reason for this is the presence in their work of a characteristic of both the first and second periods.

If we try to single out the main difference between modernity (starting with the Renaissance) and postmodernity from all other attempts to update the culture that had taken place earlier (according to the opinions of Jürgen Habermas and Natalia Avtonomova), then probably the process of human autonomy from God should be called such. Never before culture had been so explicitly or latently atheistic. Through the self-affirmation of modernity, the worldview naturally came to hyperpluralism as a manifestation of confusion, leveling not only the value hierarchy, but also the concept of value as such, affirming the infinite possibility of infinite choice, perceiving reality as a shell devoid of depth and meaning.

From this point of view, the presence of postmodern features in the modern culture seems quite understandable.

\section{CONCLUSIONS}

Thus, an analysis of a number of Jose Ortega y Gasset's works showed that in his assessment of the contemporary stage of literary and cultural creativity development, the thinker went beyond the worldview and art paradigm of the first half of the twentieth century. A significant group of researchers of his work sees enough reason to attribute him, if not to philosophers of postmodernism, then to the predecessors of this trend. The above mentioned foreign and Ukrainian researchers see in Jose Ortega y Gasset's works a rather wide range of features inherent in postmodern thinking.

This list of postmodern features in Jose Ortega y Gasset's works can be supplemented by a number of characteristics identified by the author of this article, namely: dehumanization as "the death of the author" leading to the "death of a person"; hypertectuality, perception of reality as an eternal process of formation, and not of being itself; kaleidoscopic position of the author of an artistic work; pluralism of realities and the absence of reality as such (in fact, understanding reality as a simulacrum); tricks, virtuality, imaginary in culture and art; "anti-topo-ethno-phono-centrism".

At the same time, it should be noted that the thinker did not write about the culture of the future, but in his studies characterized the culture of his present. That is, the features that are now commonly attributed to the second half of the twentieth century, José Ortega y Gasset recorded already in the beginning - the first half of the same century. In addition, we should take into account the wide 
range of scientific judgments regarding the essence and chronological framework of modern and postmodern. As well as the presence of a number of facts that speak of "contact", "flow", "complementarity" of these eras (the works of Nietzsche, Heidegger, Freud as belonging to modernity and postmodernity; avantgarde as chronologically belonging to the modern era, but with a postmodern essence). It can be assumed that the reason why the features of postmodernity are inherent in the modern era since the end of the 19th century is the fact that modernity and postmodern have a single basis - the progressive distance of a person from God. In this case, modernity (in all its historical modifications) and postmodernity are the stages of a single secularization process.

On the other hand, perhaps turning back from the distance of time between Jose Ortega y Gasset's work, and us we see what we want, or what we can see. After all, as the thinker himself noted, we see "not so much what we see, but what we know".

\section{SUMMARY}

The article deals with the problem of the lack of certainty of the essence and chronological framework of the periods of modernity and postmodernity as stages of European culture development. The facts of the presence in the period of modernity different features of postmodernity was revealed and analyzed by Jose Ortega y Gasset in his works. In his assessment of the contemporary stage of the cultural development, the thinker went beyond the worldview paradigm of the first half of the twentieth century. In cultural realities he notes signs of polycentrism, subjectivity, irony, "human death", games, hypertext, that is, features that are believed to fully manifest themselves later, in the second half of the twentieth century. This fact allows us to consider him as a harbinger of the postmodern era. At the same time, it should be noted that the thinker did not write about the culture of the future, but in his studies characterized the culture of the present to him. That is, the features that are commonly attributed to the second half of the twentieth century, José Ortega y Gasset recorded already in the beginning - the first half of the same century. The cause of this phenomenon is the presence in modernity and postmodernity a single basis - the progressing distance of a human person from God. In this case, modernity (in all its historical modifications) and postmodernity are not different periods of cultural development, but the stages of a single secularization process, the characteristics of which intersect.

\section{REFERENCES}

1. Avtonomova N.S. (1993) Vozvrashchayas' k azam: Postmodernizm i kul'tura [Returning to the basics: Postmodernism and culture]. Voprosy filosofii, no 3, pp. 17-22. (in Russian). 
2. Gorbunova L.I. (2011) Postmodern kak tendentsiya razvitiya kul'tury $\mathrm{XX}$ veka [Postmodernism as a trend in the development of culture of the twentieth century.] Vestnik MGTU, vol. 14, no. 2, pp. 265-271. (in Russian).

3. Il'in I.P. (1998) Postmodernizm ot istokov do kontsa stoletiya: evolyutsiya nauchnogo mifa. [Postmodernism from its beginnings to the end of the century: the evolution of scientific myth]. Moscow: Intrada. $250 \mathrm{p}$. Retrieved from: http://www.gumer.info/bogoslov_Buks/Philos/Ilin_Mod/ index.php (in Russian).

4. Kutyrev V.A. (2006) Filosofiya postmodernizma [The philosophy of postmodernism], Nizhniy Novgorod: Volgo-Vyatskoy akademii gosudarstvennoy sluzhby, 95 p. (in Russian).

5. Lisokolenko T.V. (2015) Igra kak fenomen kul'tury v opisaniyakh Y. Kheyzingi i Kh. Ortegi-i-Gasseta [The game as a cultural phenomenon in the descriptions of J. Hazinga and J. Ortega y Gasset] Aktualni problemy filosofii ta sotsiolohii. pp. 88-90. (in Russian).

6. Moklytsia M. (2016) Poniattia "zhanr" i "styl" yak fenomen humanitarnykh nauk ("Rozdumy pro Dona Kikhota" Kh. Ortegy-i-Hasseta) [The notion of "genre" and "style" as a phenomenon of the humanities ("Reflections on Don Quixote" by J. Ortega y Gasset)] Literaturnyi protses: metodolohiia, imena, tendentsii. Filolohichni nauky. no. 8, p. 20-24. (in Ukrainian).

7. Orteha-i-Haset Kh. (1994) Dumky pro roman [Thoughts on a Novel] / per. V. Sakhna. Vybrani tvory [Selected Works.] Kyiv: Osnovy, pp. 273-305. Retrieved from: https://www.ukrlib.com.ua/world/printit.php?tid=3815. (in Ukrainian).

8. Ortega-i-Hasset Kh. (2012) Rozdumy pro Dona Kikhota [Reflections on Don Quixote] / per. z isp. H. Verby. Kyiv: Dukh i Litera, 216 p. (in Ukrainian).

9. Orteha-i-Hasset Kh. (2009) Ubohist i blysk perekladu. [Poverty and brilliance of translation] Vsesvit. no. 11-12. Retrieved from: http://www.vsesvit-journal.com/old/content/view/659/41/ (in Ukrainian).

10. Ortega-i-Gaccet Kh. (1991) Estetika. Filosofiya kul'tury. [Aesthetics. Philosophy of Culture] Moscow: Iskusstvo, 588 p. (in Russian).

11. Panishchev A.L. (2009) Kul'turologiya [Cultural studies]. Moscow: Soyuz, 350 p. (in Russian).

12. Pronkevych O. V. (2006) "Rozdumy nad Kikhotom" Kh. Ortehy-iHasseta: ispanska natsionalna identychnist yak kontaktna zona. ["Reflections on Quixote" by J. Ortega y Gasset: Spanish National Identity as a Contact Zone] Naukovi pratsi MDHU im. Petra Mohyly, vol. 59, no. 46, pp. 42-47. (in Ukrainian).

13. Ratnikov V.P. (2002). Postmodernizm: istoki, stanovlenie. [Postmodernism: Origins, Formation] Filosofiya $i$ obshchestvo. no. 4, pp. 120-132. (in Russian). 
14. Flier A.Ya. (2000). Kul'turologiya dlya kul'turologov. [Cultural Studies for Culturologists] Moscow: Akademicheskiy Proekt. 496 p. (in Russian).

15. Khabermas Yu. (2003) Filosofskiy diskurs o moderne. [Philosophical Discourse on Art Nouveau] Per. s nem. Moscow: Ves' Mir, 416 p. (in Russian).

16. Khrenov N.A. (2006). Volya k sakral'nomu [The will to the sacred]. St. Petersburg, Aleteyya. 571 p. (in Russian).

17. Abellán García J. L. (2005) Ortega y Gasset, adelantado de la postmodernidad. Meditaciones sobre Ortega y Gasset. Madrid, pp. 595-604. (in Spanish).

18. Beardslee W.A. (1989) Christ in the Post modern Age: Reflections Inspired by Jean Francois Lyotard. Varieties of Postmodern theology. Albany, p. 63-64.

19. Candón Ríos F. La literatura posmoderna española: entre el fin de la dictadura y el auge de los mass media. Verba hispanica XXIII, pp. 181-194. (in Spanish).

20. Gomes C. (2018) Ortega y Gasset: no caminho da hipermodernidade. Uma visão projetiva da Contemporaneidade. Ideas y Valores, vol. 67.168. pp. 43-57. (in Spanish).

21. Martín Francisco J. (2006) La teoría de la traducción en Ortega. Centro Virtual Cervantes. pp. 1-10. Retrieved from: https://cvc.cervantes.es/ literatura/aispi/pdf/06/06_245.pdf (in Spanish).

22. Ordóñez López P. (2006) Revisión del pensamiento de Ortega y Gasset sobre la traducción a la luz de la tradición hermenéutica. SENDEBAR (Revista de la FTI). no. 17, pp. 49-60. (in Spanish).

23. Ovejero Bernal A. (2000) Ortega y Gasset un pensador prepostmoderno altamente fertil para la psicologia postpositivista del siglo XXI. Revista de historia de psicilogia. vol.21. no 2-3, pp. 35-52. (in Spanish).

24. Sánchez Miñambres J. (1996) Ortega y el nacimiento de la posmodernidad. El Basilisco (Oviedo). no. 21, pp. 62-63. (in Spanish).

\section{Information about the author:} Olha Smolina,

Prof., Doctor of Science in Culture Studies

Professor of philosophy, culture studies and informational activity Department Volodymyr Dahl East Ukrainian National University pr. Central 59-a, Severodonetsk, 93400, Ukraine ORCID ID: orcid.org/0000-0003-2369-3738 